\title{
Are DMI+Qol Premixes Applied during Flowering Worth for Protecting Wheat Yields from Fusarium Head Blight? A Meta-analysis
}

Jhonatan P. Barro', Flávio M. Santana², Maíra R. Duffeck, Franklin J. Machado', Douglas Lau², Cheila C. Sbalcheiro², Carlos A. Schipanski ${ }^{3}$, Débora F. Chagas ${ }^{3}$, Wilson S. Venancio ${ }^{4}$, Leandro J. Dallagnol ${ }^{5}$, Caroline W. Guterres $^{6}$, Paulo Kuhnem ${ }^{7}$, Heraldo R. Feksa ${ }^{8}$, Emerson M. Del Ponte*

${ }^{1}$ Departamento de Fitopatologia, Universidade Federal de Viçosa, 36570-000, Viçosa, MG, Brazil

${ }^{2}$ Laboratório de Fitopatologia, Embrapa Trigo, 99050-970, Passo Fundo, RS, Brazil

${ }^{3}$ G12 Agro Pesquisa e Consultoria Agronômica, 85015-450, Guarapuava, PR, Brazil

${ }^{4}$ Estação Experimental Agrícola Campos Gerais (EEACG), 84130-000, Ponta Grossa, PR, Brazil

${ }^{5}$ Departamento de Fitossanidade, Universidade Federal de Pelotas, 96010-970, Pelotas, RS, Brazil

${ }^{6}$ CCGL Tecnologia, 98005-970, Cruz Alta, RS, Brazil

7 Biotrigo Genética Ltda.,
99052-160, Passo Fundo, RS, Brazil
${ }^{8}$ Fundação Agrária de Pesquisa
Agropecuária, 85139-400,
Guarapuava, PR, Brazil

*Corresponding author: Emerson M. Del Ponte, delponte@ufv.br

Data and codes available: https://osf.io/ge7ux/

Commented code: https://git.io/JUDyk

\begin{abstract}
Fusarium head blight (FHB), caused mainly by Fusarium graminearum, is best controlled with demethylation inhibitor (DMI) fungicides applied during flowering. However, the use of premixes of DMI and quinone outside inhibitor (QoI) fungicides to control FHB has increased in Brazil, but the individual results are inconsistent. Data on FHB severity and wheat yields measured in field experiments conducted in Brazil were gathered from both peer- and non-peer-reviewed sources published from 2000 to 2018. After applying selection criteria, 35 bibliographic sources, contributing 73 (50\% from cooperative trials) trials, were identified. At least one of four DMI+QoI premixes and one tebuconazole (TEB) treatment, applied mostly twice (full-flowering and 10 days) tested in at least 14 trials and three year each, were present in a selected trial. Estimates of percent control (and respective 95\%CI) by a network model ranged from $44.1 \%$ (pyraclostrobin + metconazole applied once; $32.4-53.7$ ) to 64.3\% (pyraclostrobin + metconazole; 58.4 - 69.3); the latter not differing from TEB (59.9\%, 53.6 - 65.3). Yield response was statistically similar for pyraclostrobin + metconazole $(532.1 \mathrm{~kg} / \mathrm{ha}$, $441-623)$ and trifloxystrobin + prothioconazole $(494.9 \mathrm{~kg} / \mathrm{ha}, 385$ - 551), and both differed statistically from a group composed of TEB (448.2 kg/ha, 342 - 554), trifloxystrobin + TEB (468.2 kg/ha, 385 - 551), azoxystrobin + TEB (462.4 kg/ha, 366 - 558) and pyraclostrobin + metconazole applied once $(413.7 \mathrm{~kg} / \mathrm{ha}, 308$ 518). The two categories of FHB index (7\% cut off) and yield $(3,000$ $\mathrm{kg} / \mathrm{ha}$ ), both in the non-treated check, did not explain the heterogeneity in the estimates. The probability of not-offsetting control costs was generally lower than 0.45 for scenarios considering two sequential sprays of the low-cost TEB or one spray of pyraclostrobin + metconazole as management choices. The envisioned enhanced economic return, solely based on yield response, from using two sprays of DMI+QoI premixes to control FHB should be seen with caution given the marginal levels of profitability.
\end{abstract}

Keywords: systematic review; chemical control, Fusarium graminearum, profitability, strobilurin-triazole premixes 


\section{Introduction}

Fusarium head blight (FHB, or wheat scab), caused mainly by Fusarium graminearum, is one of the most economically damaging wheat diseases worldwide, including Brazil (Del Ponte et al. 2015; Goswami and Kistler 2004). FHB-affected wheat crops produce small-sized, shriveled and discolored kernels, which may contain dangerous mycotoxins produced by the fungus (Ponts 2015). The presence of mycotoxins at certain levels may downgrade grain price or even reject the product at the elevators in countries where maximum limits have been promulgated (ANVISA 2011; 2017; McMullen et al. 2012). In Brazil, model-based estimates of relative losses to wheat yield due to FHB during more than 25 years averaged 10\%, ranging from 3 to 25\% (Duffeck et al. 2020). The estimates of decadal averages in yield losses were in agreement with reports from field experiments that suggested FHB being of no economic importance prior to the 1990s (Casa et al. 2004; Reis et al. 1996). Multi-toxin surveys in commercial wheat produced in Brazil have shown that trichothecenes, such as deoxynivalenol (DON) and nivalenol, as well as zearalenone, are common contaminants (Del Ponte et al. 2012; Duffeck et al. 2017; Mallmann et al. 2017).

Although several methods have been evaluated for managing FHB, effective and economic control has been achieved using fungicides applied during full flowering in combination with the use of less susceptible cultivars (Mesterházy et al. 2003; Wegulo et al. 2011; 2015; Willyerd et al. 2012). Among the fungicides, those of the demethylation inhibitor (DMIs) group have been ranked more consistently as the best options to suppress FHB and DON, but their control efficacy varies among the different active ingredients (Machado et 
al. 2017; Mesterházy et al. 2011; 2018; Paul et al. 2008). For example, metconazole or prothioconazole, applied solely or mixed together, have provided the highest reduction in FHB and DON than tebuconazole and propiconazole applied alone in the United States (Paul et al. 2008; 2018). In Brazil, a meta-analysis study showed wheat yields numerically higher with two sprays of tebuconazole $(+100 \mathrm{~kg} / \mathrm{ha}$ on average), which performed better than propiconazole and carbendazim (Machado et al. 2017). A 28-year simulation study used the meta-analytic estimate of yield gain from a second spray of tebuconazole (Machado et al. 2017) when linking historical weather, a crop model, a disease model, and a model relating FHB index and yield. Results of that study showed that the risk of not-offsetting the costs was generally higher for two sprays given the variability in the disease risk in the historical weather for a location in southern Brazil (Duffeck et al. 2020).

Strobilurins (QoIs) are generally not recommended for FHB control due to their lower efficacy than triazoles (Bolanos-Carriel et al. 2020; Feksa et al. 2019; Magan et al. 2002; Pirgozliev et al. 2002). In addition, low reduction, or even an increase, in DON in the grain relative to untreated check plots of wheat in the field treated with the QoI azoxystrobin have been reported (Ellner 2005; Feksa et al. 2019; Mesterhazy et al. 2003; Simpson et al 2001). The underlying mechanisms leading to the increase in mycotoxin production by QoI are not entirely clear and levels of increase seem to be dependent on the active ingredient. Recently, several QoIs including coumoxystrobin, picoxystrobin, fluoxastrobin, azoxystrobin, fenaminstrobin and pyraclostrobin were associated with DON production by up-regulating the expression of Tri5 and Tri6 genes and increasing acetil-CoA production (Duan et al. 2020). 
Although the use of QoI to manage FHB is not encouraged, benefits from their use, especially when mixed with a DMI, include extended protection against foliar diseases including powdery mildew, tan spot and rusts (Barro et al. 2017; Blandino et al. 2006; Paul et al. 2018; Ransom and McMullen 2008; Willyerd et al. 2012). Studies conducted in controlled conditions have shown that QoIs can alter wheat physiology, resulting in enhanced stress tolerance, increased photosynthesis rate and yield (Blandino et al. 2011; Oerke et al. 2001; Paul et al. 2018). Therefore, the possibility of extending the flag leaf life may result in better yields especially in disease-conducive environments (Blandino et al. 2011; Wegulo et al. 2011).

In Brazil, DMI+QoI premixes have been evaluated for many years, but a plethora of new data became available after the establishment of an industry-partnered network of cooperative fungicide trials (CFTs) in 2011 (Santana et al. 2012, 2014, 2016 a,b,c, 2019 a,b, 2020). Analyses of those data, both at the trial level and all trials combined within a year, do not provide a clear picture whether and under which conditions the use of premixes is justified and profitable for protecting wheat yields. Academic research in the country has shown inconsistent results when QoI-amended premixes were compared to single active ingredients or other premixes. For example, in a four-trial study in Rio Grande do Sul state, significant differences in yield response favored the pyraclostrobin + metconazole other than metconazole alone in some trials (Spolti et al. 2013). Conversely, in a four-year study in Paraná State, triazole and benzimidazole fungicides performed better than the DMI+QoI premixes with regards to FHB and DON control (Feksa et al. 2019). Similarly, in the United States, studies have reported flowering applications of DMIs as more effective in reducing 
FHB and DON, but most of the data from that country are based on applications of a QoI alone (Bolanos-Carriel et al. 2020) or DMI+QoI premixes prior to anthesis (Paul et al. 2018).

To resolve inconsistencies on treatment effects, meta-analysis is a useful approach to synthesize results from several bibliographic sources, which are selected following a defined criteria, to estimate the significance, size and uncertainty of the effect of a treatment of interest (Madden and Paul 2011; Madden et al. 2016). The method has gained popularity to summarize the effect of treatments in plant disease management, especially for data from uniform fungicide trials, including FHB research (Barro et al. 2019; Dalla Lana et al. 2018; Edwards Molina et al. 2019; Machado et al. 2017; Paul et al. 2008, 2018). This latter source of data is critical to minimize issues associated with publication bias, or when larger than average effects are more likely to be published (Mueller et al. 2013; Pannucci and Wilkins 2010).

In this study, we combined FHB index and wheat grain yield data gathered from peerand non peer-reviewed bibliographic sources and CFTs. The final dataset spanned 15 years (2000 to 2018) of experiments conducted at 25 locations in the main wheat-producing regions in southern Brazil. Our objectives were to: 1) obtain meta-analytic estimates of FHB control efficacy and wheat yield response to selected DMI+QoI premixes; 2) test whether at least portion of the heterogeneity in treatment effects could be explained by baseline levels (non-treated pots) of disease or yield; and 3) calculate the profitability of representative fungicide treatments, using meta-analytic estimates, based on the risk of not offsetting the fungicides cost. 


\section{Materials and Methods}

\section{Data source and criteria for trial and fungicide selection}

Data were obtained from both peer and non peer-reviewed articles/reports (hereafter studies) on fungicide efficacy including the CFT-FHB (Ensaios cooperativos de giberela).

First, a search was conducted in Google Scholar database using the following English keywords such as: "wheat", "Fusarium head blight" and "fungicide"; as well as the Portuguese keywords: "trigo", "giberela", "fungicida", "eficácia", because many studies conducted in Brazil were published in the native language and local venues. The publication period in the search was restricted from 2000 to 2018. A total of 50 studies were found (as of March 2020). After duplicate removal $(\mathrm{n}=1), 49$ studies were scrutinized to check those conforming with the following criteria: a) field trial conducted after 2000 year in Brazil; b) means of FHB index (\%) and/or wheat grain yield (kg/ha), together with a measure of sampling variance, reported in tables or charts; c) a non-treated check treatment included for comparison. Forty-two studies did not match the criteria and were excluded. Other sources included the literature section of the studies, abstracts and posters presented at scientific meetings and available in digital format. These were scrutinized and 22 studies were selected. Finally, we used all data available at the annual reports of the Ensaios cooperativos de giberela website, totaling six reports (http://www.ensaioscooperativos.net/). The selected studies were further inspected to select the treatments of interest for analysis. To be included in the meta-analysis, a DMI+QoI premix treatment, as well as DMI for comparison, should have been evaluated in 
at least 14 trials and during three years, applied either singly or twice during flowering. A total of 113 independent trials (from 35 studies) met the criteria.

\section{Database description}

Data from CFTs conducted during an eight-year period (2011 to 2018) constituted the largest portion (50\%) of the trials. The remaining trials were obtained from the literature, such as thesis (6\%) and extended abstracts or manuscripts (44\%) published from 2000 to 2015. The total period encompassed 15 years (2000 to 2018) and the trials were conducted at 25 locations in three states of south of Brazil (RS, PR, and SC). The number of trials differed between the two response variables (FHB index and yield). There were 65 trials for FHB index and 73 trials for yield because FHB index was not obtained in all trials.

Four premixes met the criteria and tebuconazole was included for comparison (Table 1). Most treatments (all trials from the CFTs) were tested with two applications: first spray at the mid- flowering and the following 10 days later. For one premix treatment (PYRA + METC), data were available for one spray (peer-reviewed literature only). This treatment was included in the analysis to compare the single versus two applications of a representative premix (Table 1). 
Table 1. Fungicide treatments applied for controlling Fusarium head blight in wheat, evaluated in 73 fungicide trials conducted from 2000 to 2018 across three Brazilian states (PR, RS and SC).

\begin{tabular}{lcllcc}
\hline Fungicide a.i. & $\mathbf{n}^{\mathbf{a}}$ & Study code & $\begin{array}{l}\text { Commercial } \\
\text { name }\end{array}$ & Sprays $^{\mathbf{b}}$ & Dose $^{\mathbf{c}}$ \\
\hline untreated & 73 & CHECK & - & - & - \\
azoxystrobin + tebuconazole & 25 & AZOX + TEBU & Azimut & 2 & 0.50 \\
pyraclostrobin + metconazole & 23 & PYRA + METC & Opera Ultra & 1 & 0.75 \\
pyraclostrobin + metconazole & 66 & PYRA + METC & Opera Ultra & 2 & 0.75 \\
trifloxystrobin + prothioconazole & 41 & TFLX + PROT & FOX & 2 & 0.50 \\
trifloxystrobin + tebuconazole & 36 & TFLX + TEBU & Nativo & 2 & 0.75 \\
tebuconazole & 25 & TEBU & Folicur & 2 & 0.75
\end{tabular}

${ }^{a}$ number of trials that each fungicide was evaluated;

${ }^{\mathrm{b}}$ number of applications: first spray at the beginning of flowering (25\% to 50\%) and the following 10 days apart;

${ }^{\mathrm{c}}$ Dose (L/ha) for each fungicide.

\section{Meta-analytic model}

Estimates of the control efficacy and yield response were obtained from fitting an arm-based network model, also known as two-way unconditional linear mixed model, to the data. In this approach, the model is fitted directly to data on treatment means (absolute or log-transformed) (Machado et al. 2017; Madden et al. 2016; Paul et al. 2008) and not to the pairwise differences of treatments, known as contrast-based models. While means of FHB index were log-transformed, no transformation or standardization was required to obtain the mean absolute difference in yield, given the statistical properties of the data (Fig. S1). The arm-based model can be written as Equation 1: 


$$
Y_{i} \sim N\left(\mu, \Sigma+S_{i}\right)
$$

where $Y_{i}$ is the vector of $\mathrm{L}(\log$ of the means of yield or FHB index) or absolute yield for the six treatments plus the nontreated check for the ith study, $\mu$ is a vector representing the mean of $Y_{i}$ across all studies, $\sum$ is a $7 \times 7$ between-study variance-covariance matrix (for the seven treatments, including the nontreated check), and $S_{i}$ is a within-study variance-covariance matrix for the $i$ th study. $\mathrm{N}$ indicates a multivariate normal distribution.

The within-study variability (sampling variance) of $L$ and $D$ was calculated from the reported coefficient of variation (CV) or the mean square error (MSE); the latter when the data were available at the replicated plot level, as described (Machado et al. 2017; Paul et al. 2008, 2010). An unstructured (UN) matrix $\sum$ was used, given its better fit to the data than other structures such as heterogeneous compound symmetry (HCS) (data not shown). Maximum likelihood estimation models were fitted to the data using the rma.mv function of metafor package (Viechtbauer 2010) of R (R Core Team 2019).

To express the model estimates in more intuitive responses such as percent FHB control $(\bar{C})$ and percent yield increase $(\bar{Y})$ we calculated the differences of the estimated means of the $\operatorname{logs}\left(\bar{L}_{\mathrm{IND}}\right.$ and $\left.\bar{L}_{\mathrm{YLD}}\right)$ which equals the ratio of the two means (Paul et al. 2008). The $\bar{C}$ and $\bar{Y}$ values and their 95\% confidence intervals (CIs) were obtained by back-transforming $\bar{L}_{\mathrm{IND}}$ and $\bar{L}_{\mathrm{YLD}}$ and the respective upper and lower limits of their 95\% CIs as described in Equations 2 and 3. 


$$
\begin{aligned}
& \bar{C}=\left(1-\left(\exp \left(\bar{L}_{I N D}\right)\right) \times 100\right) \\
& \bar{Y}=\left(\left(\exp \left(\bar{L}_{Y L D}\right)-1\right) \times 100\right)
\end{aligned}
$$

The yield difference $(\bar{D})$ was calculated directly after model fitting by subtracting estimated means of fungicide treatment and nontreated check (Madden et al. 2016).

When performing a multi-arm network meta-analysis, assessment of the inconsistency or the extent to which different sources of evidence are compatible is an important component (Higgins et al. 2012). The most important source is known as "design inconsistency" for which a design-by-treatment interaction provides a useful general framework for investigating inconsistency (Higgins et al. 2012; Madden et al. 2016; Piepho et al. 2014). We used a factorial-type ANOVA model to determine the significance of the treatment $\mathrm{x}$ design interaction, evaluated based on the Wald test statistic. The null hypothesis suggests that the network is consistent (Madden et al. 2016; Piepho et al. 2014). Eleven different designs (here design refers to the set of treatments in the trial) were found in the trials reporting both FHB index and yield response.

\section{Analysis of moderator effects}

The model was expanded to include categorical or continuous moderator variables that could explain, at least portion of, the heterogeneity of the effects across trials (Madden et al. 2016). As categorical, we created baselines for FHB disease index and wheat grain yield based on the median of the mean values in the nontreated check. The FHB index class was divided into two groups, or baselines, representing low (<7\% FHB index) and high ( $\geq 7 \%$ FHB index) disease scenarios. The defined baseline (7\% FHB index) has been used to separate 
light from moderate FHB epidemic levels in Brazil (Del Ponte et al. 2005), which is close to the 10\% FHB index used in the United States to define an epidemic case (De Wolf et al. 2003). The baseline yield was defined as low ( $<3000 \mathrm{~kg} / \mathrm{ha})$ or high $(\geq 3000 \mathrm{~kg} / \mathrm{ha})$ based on the median yield in the nontreated check plot. As continuous moderators, FHB index in the nontreated check and year were included in the model; the latter to check whether there was any trend of decline in fungicide efficacy over time (Dalla Lana et al. 2018).

The moderator variables were included in the model and tested using a Wald-type chi-square test to determine if the moderator variables directly affected the differences in logs of FHB index and the non-transformed yield values (Paul et al. 2008).

\section{Economic risk and profitability of fungicides}

With the estimates of mean yield difference $(\bar{D})$ and the respective between-study variance $(\hat{\tau})$ obtained from the meta-analysis, we calculated risk probability $\left(\mathrm{P}_{\text {loss }}\right)$ of not offsetting the costs of fungicide plus application $\left(\mathrm{F}_{\mathrm{C}}\right)$ as described in Equation 4 used in previous studies (Barro et al. 2019; Machado et al. 2017; Paul et al. 2008):

$$
P_{\text {loss }}=1-\Phi\left[\bar{D}-\left(F_{C} / W_{P}\right) / \sqrt{\widehat{\tau}}\right]
$$

where $\Phi$ is the cumulative standard-normal function, $W_{P}$ is the wheat price, and $F_{C}$ is the fungicide costs (product + application).

Based on the meta-analysis results, three treatments were selected for comparison: the best performing premix (PYRA + METC) applied once or twice, was compared with TEBU applied twice. For each fungicide treatment, 25 combinations were simulated (five 
$W_{P}$ x five $F_{C}$ ), totaling 125 scenarios. For the calculations, we used an exchange rate as of July 2020 (\$5.2 BRL = 1 U\$) and a central value of fungicide price practiced in the 2019/20 crop season. The total costs (fungicide + operational cost of 10.00 U\$/ha) for each fungicide treatment were: PYRA + METC $=50.00 \mathrm{US} /$ ha (the half for one spray); and TEBU $=35.00 \mathrm{US} / \mathrm{ha}$. The central value for wheat price (160 U\$/ton) was obtained from the data gathered at the AGROLINK database for three wheat-producing states (Rio Grande do Sul,

Paraná, and Santa Catarina) (AGROLINK 2020). Tile plots of the probability classes of not offsetting on fungicide costs were produced for each fungicide.

\section{Results}

\section{FHB index and yield data at the trial level}

FHB index in the nontreated check plots of the studies ranged from 0.08 to $92.2 \%$ (median 7.4\%) with no evident pattern of significant variation associated with season or state (Fig. 1; Fig S1). Over the years, the highest (36.8\%) and the lowest (3.8\%) median FHB index in the untreated check were recorded in the 2000 and 2008 seasons, respectively (Fig. 1A). Similarly, baseline yield ranged from 67 to $6,048 \mathrm{~kg} / \mathrm{ha}$ (median 2,993 $\mathrm{kg} / \mathrm{ha}$ ) across the trials. Baseline yields were generally higher in Paraná state (median 3,358 kg/ha) than Rio Grande do Sul and Santa Catarina states combined (median 2,838 kg/ha) (Fig. S2B). There was a general trend of decreased FHB index and increased yield in the fungicide treatments compared with the untreated check (Fig. 1A,B). 
A
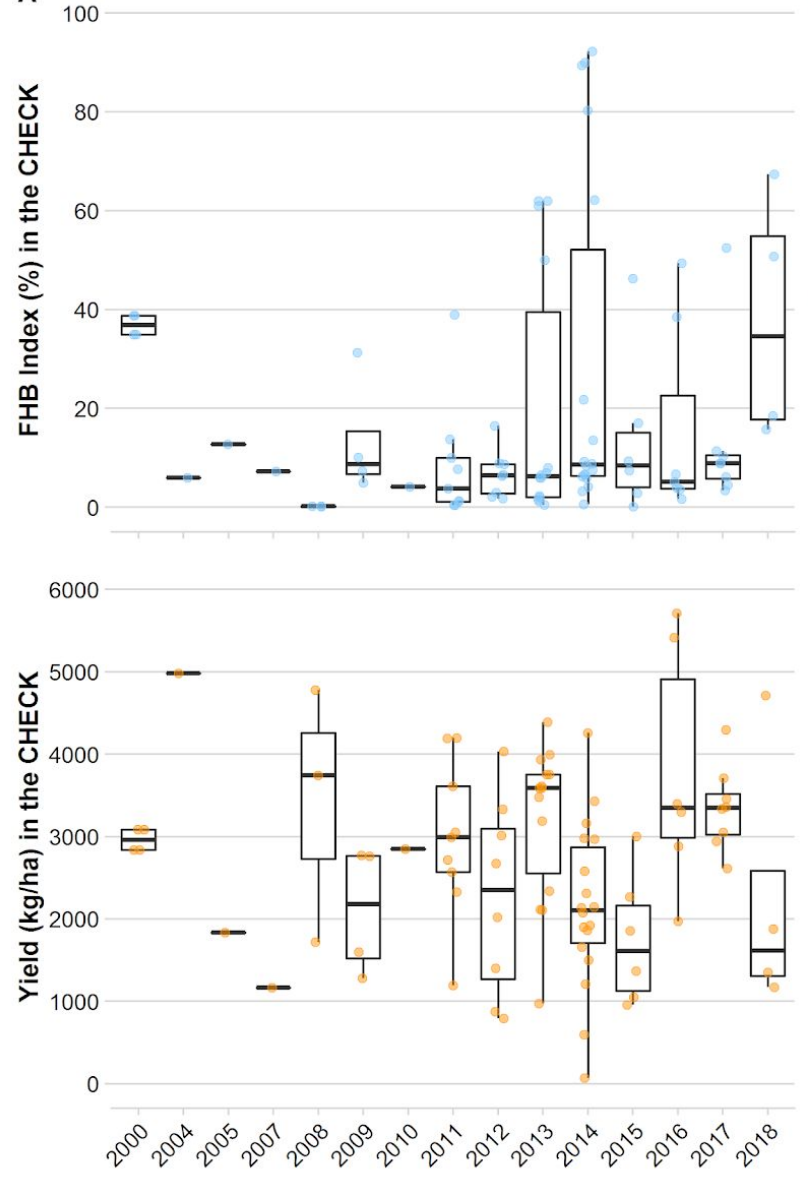

Crop Seasons
B 100
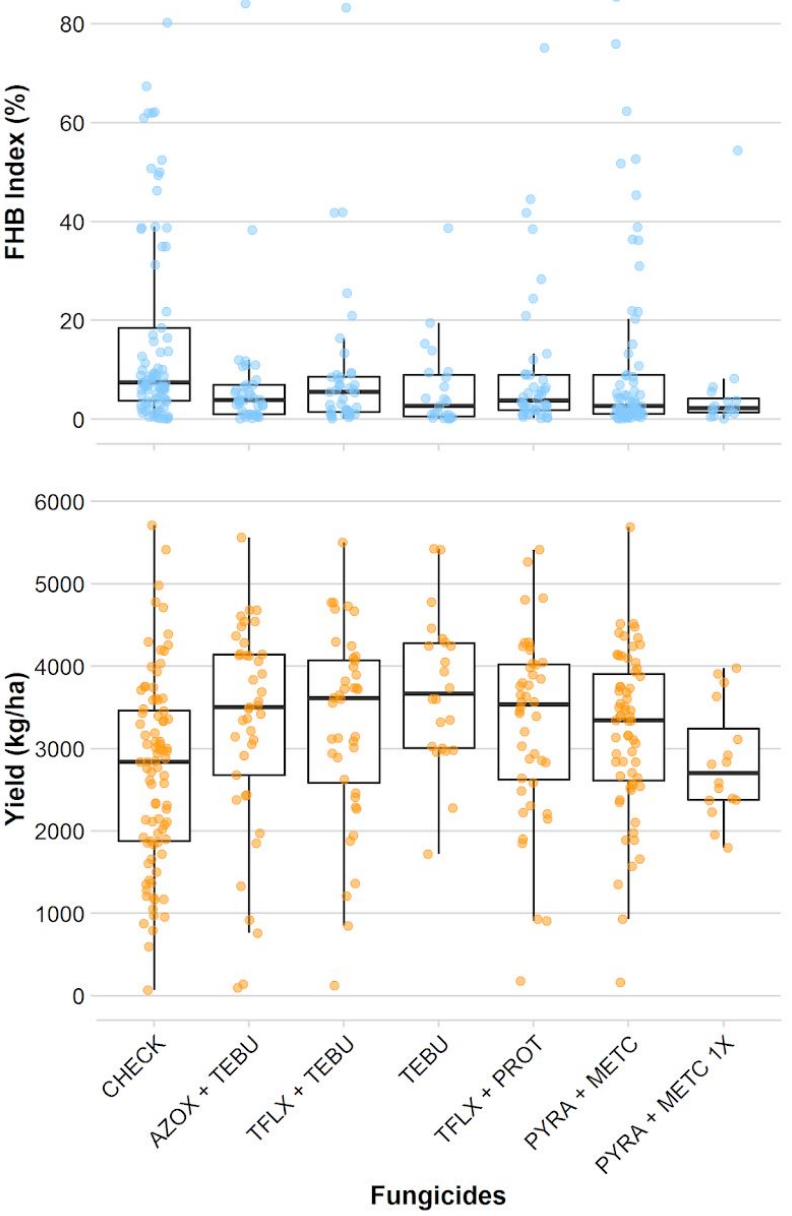

Fig. 1. Box plots for the within-season variation across trials in the nontreated check (A), and means for a set of fungicide treatments (B) of FHB Index (\%) and wheat grain yield (kg ha $^{-1}$ ) obtained from 73 trials conducted during 15 years across three Brazilian states (PR, RS and SC). The thick horizontal line inside the box represents the median, the limits of the box represent the lower and upper quartiles, and the circles represent yearly means of each treatment (See Table 1 for information on the fungicide treatments).

\section{Percent FHB control}

Percent control efficacy, obtained from back-transformation of the estimated differences of the log-transformed FHB index in the fungicide-treated and nontreated plots, ranged from 44.1 to $64.3 \%$. Two sprays of PYRA + METC or TFLX + PROT reduced FHB index by at 
least $60 \%$ and did not differ significantly between them $(\mathrm{P}>0.42)$, neither to TEBU $(59.8 \%)$, but differed $(\mathrm{P}<0.05)$ from AZOX + TEBU $(58.7 \%)$. The latter did not differ significantly from TEBU $(P=0.41)$ and TFLX + TEBU $(58.4 \% ; P=0.85)$. All fungicides differed from PYRA + METC applied once, which showed the least level of control (44.1\%) (Table 2). The difference in percent control efficacy between the most and least effective fungicide was 20.2 percent points. The Wald test for the treatment $\mathrm{x}$ design interaction showed that the network was consistent $(P=0.49)$.

Table 2. Overall means and respective confidence intervals of log response ratio $(\bar{L})$ and calculated percent control $(\bar{C})$ of Fusarium Head Blight (FHB) relative to untreated check provided by six fungicides evaluated during 15 years (2000 to 2018) across 65 studies conducted in three Brazilian states (PR, RS and SC).

\begin{tabular}{|c|c|c|c|c|c|c|c|c|c|}
\hline \multirow[b]{2}{*}{ Fungicide $^{a}$} & \multirow[b]{2}{*}{$k^{\mathrm{b}}$} & \multicolumn{5}{|c|}{ Effect Size } & \multicolumn{3}{|c|}{ FHB control (\%) } \\
\hline & & $\bar{L}$ & $\mathrm{SE}(\bar{L})$ & $\mathrm{CI}_{\mathrm{L}}^{\mathrm{c}}$ & $\mathrm{CI}_{\mathrm{U}}^{\mathrm{c}}$ & P value & $\bar{C}$ & $\mathrm{CI}_{\mathrm{L}}^{\mathrm{c}}$ & $\mathrm{CI}_{\mathrm{U}}^{\mathrm{c}}$ \\
\hline PYRA + METC & 60 & -1.0299 & 0.0774 & -1.1815 & -0.8783 & $<0.0001$ & 64.29 & 58.44 & 69.31 \\
\hline TFLX + PROT & 42 & -0.9845 & 0.0821 & -1.1454 & -0.8235 & $<0.0001$ & 62.63 & 56.11 & 68.19 \\
\hline TEBU & 14 & -0.9137 & 0.0742 & -1.0592 & -0.7682 & $<0.0001$ & 59.89 & 53.61 & 65.32 \\
\hline $\mathrm{AZOX}+\mathrm{TEBU}$ & 25 & -0.8844 & 0.0775 & -1.0363 & -0.7326 & $<0.0001$ & 58.70 & 51.93 & 64.52 \\
\hline TFLX + TEBU & 40 & -0.8768 & 0.0799 & -1.0334 & -0.7202 & $<0.0001$ & 58.38 & 51.33 & 64.42 \\
\hline PYRA + METC $_{1 X}$ & 16 & -0.5816 & 0.0966 & -0.7710 & -0.3921 & $<0.0001$ & 44.09 & 32.43 & 53.74 \\
\hline
\end{tabular}

${ }^{a}$ See Table 1 for complete information of the evaluated fungicides;

${ }^{\mathrm{b}}$ number of trials that each fungicide was evaluated;

${ }^{\mathrm{c}}$ upper $\left(\mathbf{C I}_{\mathrm{U}}\right)$ and lower $\left(\mathbf{C I}_{\mathrm{L}}\right)$ limits of the $95 \%$ confidence interval around $\bar{L}$ and $\bar{C}$.

\section{Yield response}

The mean estimates of yield difference $(\bar{D})$ between fungicide-treated and the nontreated plots ranged from 413.7 to $532.1 \mathrm{~kg} / \mathrm{ha}$ among the premixes and tebuconazole. Yield 
response values as high as above $500 \mathrm{~kg} /$ ha were estimated only for PYRA + METC applied twice $(532.1 \mathrm{~kg} / \mathrm{ha})$, which did not differ from TFLX + PROT $(494.9 \mathrm{~kg} / \mathrm{ha})(\mathrm{P}=0.2398)$. These were followed by TFLX + TEBU (468.2 kg/ha), AZOX + TEBU (462.4 kg/ha), TEBU $(448.2 \mathrm{~kg} / \mathrm{ha})$ and PYRA + METC $_{1 \mathrm{X}}(413.7 \mathrm{~kg} / \mathrm{ha})($ Table 3$)$. The difference between the higher and lower estimated yield means was $118.4 \mathrm{~kg} / \mathrm{ha}$. Similarly, the estimated mean of the relative yield response $(\bar{Y})$ was higher $(>15 \%)$ for PYRA + METC and TFLX + PROT. These were followed by AZOX + TEBU (14.74\%), TEBU (14.68\%), TFLX + TEBU (14.66\%), and PYRA + $\operatorname{METC}_{1 \mathrm{X}}(12.97 \%)$ (Table 3). The Wald test for the treatment $\mathrm{x}$ design interaction showed that the network was consistent $(\mathrm{P}=0.99)$.

Table 3. Overall means and respective confidence intervals of unstandardized difference in wheat grain yield $(\bar{D})$ between fungicide-treated and untreated plots, and percent yield increase $(\bar{Y})$ for selected fungicide treatments evaluated during 15 years (2000 to 2018) across 73 studies conducted in three Brazilian states (PR, RS and SC).

\begin{tabular}{|c|c|c|c|c|c|c|c|c|c|}
\hline \multirow[b]{2}{*}{ Fungicide $^{\mathrm{a}}$} & \multirow[b]{2}{*}{$k^{\mathrm{b}}$} & \multicolumn{5}{|c|}{ Effect size } & \multicolumn{3}{|c|}{ Yield Return (\%) } \\
\hline & & $\bar{D}$ & $\mathrm{SE}(\bar{D})$ & $\mathrm{CI}_{\mathrm{L}}^{\mathrm{c}}$ & $\mathrm{CI}_{\mathrm{U}}^{\mathrm{c}}$ & P value & $\bar{Y}$ & $\mathrm{CI}_{\mathrm{L}}^{\mathrm{c}}$ & $\mathrm{CI}_{\mathrm{U}}^{\mathrm{c}}$ \\
\hline PYRA + METC & 70 & 532.08 & 46.40 & 441.14 & 623.02 & $<0.0001$ & 17.17 & 14.30 & 20.11 \\
\hline TFLX + PROT & 45 & 494.99 & 45.09 & 406.60 & 583.38 & $<0.0001$ & 16.21 & 13.14 & 19.37 \\
\hline TEBU & 25 & 448.20 & 54.04 & 342.27 & 554.13 & $<0.0001$ & 14.68 & 11.24 & 18.22 \\
\hline AZOX + TEBU & 25 & 462.43 & 48.92 & 366.53 & 558.32 & $<0.0001$ & 14.74 & 11.54 & 18.02 \\
\hline TFLX + TEBU & 40 & 468.24 & 42.43 & 385.08 & 551.41 & $<0.0001$ & 14.66 & 11.92 & 17.46 \\
\hline PYRA + METC $_{1 \mathrm{x}}$ & 23 & 413.72 & 53.66 & 308.53 & 518.90 & $<0.0001$ & 12.97 & 9.70 & 16.35 \\
\hline
\end{tabular}

${ }^{a}$ See Table 1 for complete information on the fungicides;

${ }^{\mathrm{b}}$ number of trials that each fungicide was evaluated;

${ }^{c}$ upper $\left(\mathbf{C I}_{\mathrm{U}}\right)$ and lower $\left(\mathbf{C I}_{\mathrm{L}}\right)$ limits of the $95 \%$ confidence interval around $\bar{D}$ and $\bar{Y}$. 
In general, the pattern of the relationship between control efficacy and yield differences was consistent. The fungicides leading to the greatest mean disease control and yield response were PYRA + METC and TFLX + PROT. Although TEBU performed similarly to TFLX + TEBU and AZOX + TEBU in control efficacy ( 59\%), yield response was slightly lower, 20 to $14.2 \mathrm{~kg} / \mathrm{ha}$, than TFLX + TEBU and AZOX + TEBU, respectively. Again, PYRA $+\mathrm{METC}_{1 \mathrm{X}}$ provided the least yield response (Fig. S3).

\section{Effect of moderator variables}

The categories of FHB index and wheat grain yield as baselines did not affect FHB index or yield $(P>0.05)$. Similarly, FHB index as continuous in the nontreated check did not affect yield $(P=0.2757)$ and year did not affect FHB index $(P=0.8672)$, suggesting no decline in fungicide efficacy over time.

\section{Probability of breaking even on fungicide cost}

The probability of loss $\left(\mathrm{P}_{\text {loss }}\right)$, or not-offsetting the costs was generally low ranged from 38.8 to $52.8 \%$. For an average benefit-cost scenario (central tile in the plot) $P_{\text {loss }}$ ranged from 41.6 to $43.2 \%$, regardless of the treatment. $\mathrm{P}_{\text {loss }}$ values increased to around $50 \%$ for higher fungicide costs and low wheat price for the selected treatments. TEBU applied twice or PYRA + METC applied once were more likely to be profitable $\left(\mathrm{P}_{\text {loss }}<45 \%\right)$ in a higher number of scenarios than the QoI-amended premix applied twice (Fig. 2). 


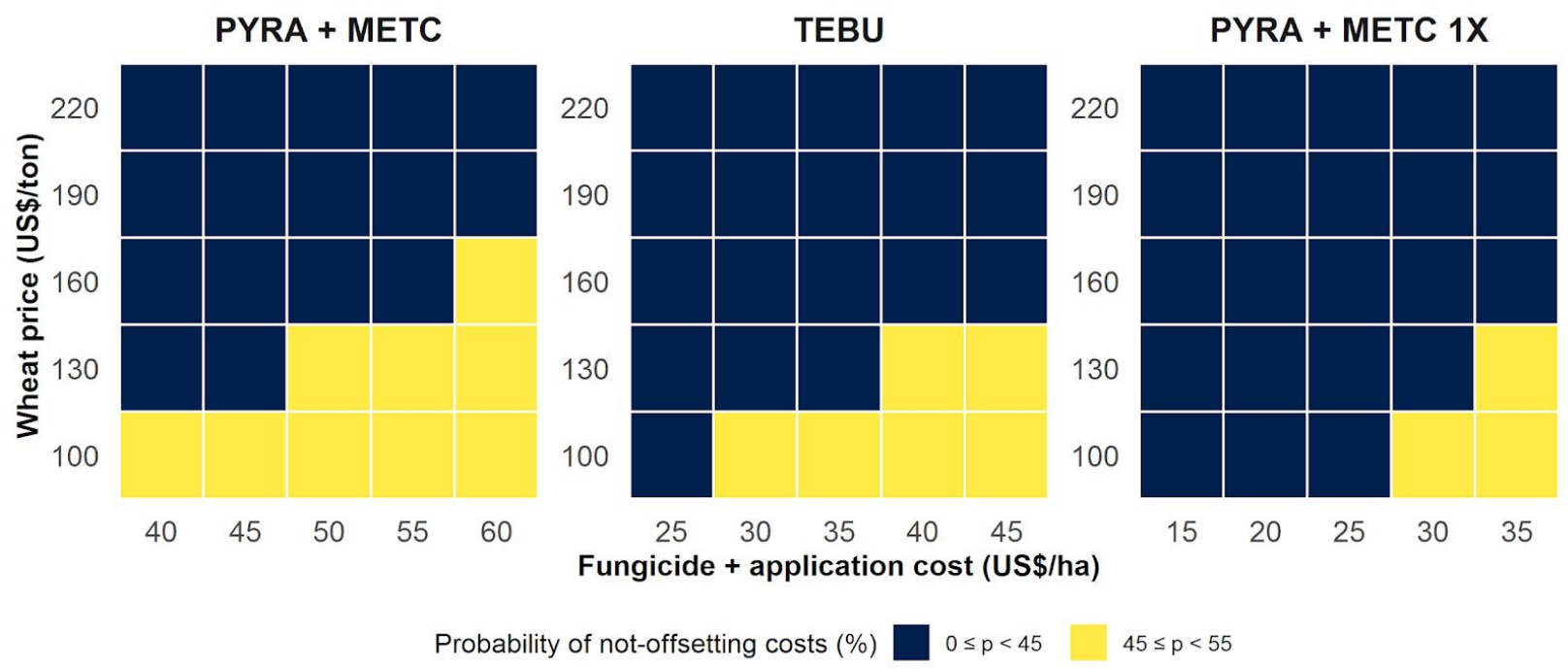

Fig. 2. Probability categories of not-offsetting on fungicide investment for different scenarios of wheat prices and fungicide costs (product price + operational costs [fixed at \$10.00 U.S./ha]) for three representative fungicide treatments (see Table 1) applied once (at flowering) or twice (10-days apart) for Fusarium Head Blight control. Probability for each fungicide treatment was calculated using the estimates of the mean difference $(\bar{D})$, and respective between-study variance $(\widehat{\tau})$, obtained from meta-analysis of data from 73 studies conducted over 15 years (2000 to 2018) in three Brazilian states.

\section{Discussion}

Quantitative summaries of the effect of DMIs applied alone or in mixture with other DMI have been made available using data from several studies conducted during the last decades (Machado et al. 2017; Paul et al. 2008, 2010). However, it was just recently that the performance of premixes that include one QoI for controlling FHB have been studied more extensively and summarized in other studies that combined data from multiple trials (Bolanos-Carriel et al. 2020; Feksa et al. 2019; Paul et al. 2018; Spolti et al. 2013). In Brazil, in particular, there has been an increasing interest, mainly by the industry, in evaluating the 
performance of DMI+QoI premixes for FHB management. In fact, only a handful of studies testing DMI+QoI premixes conducted prior to 2011 were found in our review; most of the trials being tested in the industry-partnered CFT network (Santana et al. 2012, 2014, 2016a, b, c, 2019a, b, 2020).

Our results showed that two premixes, PYRA + METC and TFLX + PROT, applied at flowering and 10 days later, provided the greatest level of control and yield response, at least numerically. However, their performance did not differ statistically from TEBU, a more affordable option included for comparison and for which the estimates in our study were very similar to those obtained in the previous study using the same dataset (Machado et al. 2017).

Our mean estimates of control efficacy for the premix PYRA + METC (64\%) were very close to the efficacy reported other recent studies, not included in our analysis, such as a two-year study (62\%) conducted in the north of RS state, Brazil (Bonfada et al. 2019) and a four-year study (64.5\%) conducted in the south of Paraná (Feksa et al. 2019). In the latter, the premixes were applied following pathogen inoculation, differing from our dataset from natural epidemics. Moreover, three DMI+QoI premixes (TFLX + PROT, TFLX + TEBU and PYRA + METC) in that study were evaluated in curative (post-inoculation) sprays, which were less effective than preventative application (pre-inoculation), corroborating previous findings (Spolti et al. 2013). Conversely, the authors reported that DMIs or carbendazim fungicides alone provided a better control efficacy $(>70 \%)$ compared to DMI+QoI premixes in all growing seasons when taking both preventative and curative applications into account (Feksa et al. 2019). Their findings corroborate the evidence of a superior performance of a single best DMI (metconazole) compared to the PYRA + METC 
premix in the United States (Paul et al. 2018). However, in US study the applications of the DMI+QoI premixes were not made during flowering, but at the heading stage, in some cases followed by one spray of DMI at flowering. This may explain in part the lower efficacy (41.8\%) (Paul et al. 2018) compared with estimates in our study for sprays of the premix at and after flowering (64\%).

Apart from the differences due to time relative to growth stage, the generally lower efficacy in DMI+QoI premixes compared with some DMIs alone or in premix, reported in some studies, has been associated with the reduced rate of DMI, which is known to be more highly effective fungicide against F. graminearum (Edwards et al. 2001; Paul et al. 2018). In our analysis, however, the rate of TEBU alone was the same $\left(200 \mathrm{gL}^{-1}\right)$ as in the two premixes (TFLX + TEBU and AZOX + TEBU) and did not affect control efficacy as well as yield response. Similarly, Dardis and Walsh (2000) also reported comparable levels of FHB control when testing AZOX + MET and TFLX + METC with the corresponding DMI pair alone. Bonfada et al. (2019) reported similar control efficacy and yield response between PYRA + METC and single-DMI METC, both applied at anthesis and seven days later. In Italy, Blandino et al. (2006) reported greater control efficacy of the premix azoxystrobin + tebuconazole (79\%) compared to tebuconazole (64\%) with applications made at mid-anthesis.

Yield benefits from the use of DMI+QoI premixes for FHB control on wheat grain yields has been linked to a broad spectrum of protection, due to the different modes of action, that could be extended to foliar diseases, especially under high disease pressure conditions (Bolanos-Carriel et al. 2020; Blandino et al. 2011; Spolti et al. 2013; Wegulo et al. 2011). For instance, Blandino et al. (2006) reported a $8.7 \%$ increase in yield by applying 
AZOX+TEBU compared to two DMIs applied alone (tebuconazole and prochloraz). Those reports agree with our findings of yield response for PYRA + METC being greater than TEBU (83.8 kg/ha). Information on the presence and intensity of foliar diseases was not available in the primary studies used in our analysis. However, the two groups of trials representing low or high baseline yield may be indicative of conditions that are more or less favorable for foliar diseases. When tested as moderator, we failed to reject the hypothesis that yield response is not influenced by the baseline yield. This result agrees with a previous meta-analysis on the effect of tebuconazole, propiconazole and benzimidazole fungicide to control FHB in wheat, for which the estimates were not affected by disease pressure (Machado et al. 2017).

Using the means and respective uncertainty of the estimates in a benefit-cost risk analysis, the one-time (full flowering) spray of PYRA + METC was generally of lower risk of loss (not offsetting costs) than two sprays of this mixture or TEBU applied twice. The economic benefit from an additional spray of tebuconazole for FHB control has been questioned in previous studies. However, caution is needed because only yield protection, not mycotoxin reduction, which can contribute to economic loss in some situations, was not taken into account in those studies, as well as in our current study (Duffeck et al. 2020; Machado et al. 2017).

Results of our profitability analysis using data representative of specific experimental conditions - two sequential sprays of the same commercial fungicide, suggest that some DMI+QoI premixes can be as effective and affordable as tebuconazole in reducing FHB index and increasing wheat grain yield. This is important information for grower making more informed decisions to manage FHB economically. Current 
recommendations vary across the main wheat regions. In general, one spray of a DMI+QoI, premix at flowering has become standard practice, but two sprays are common in production situations that target high yield and quality such as in southern PR State (Feksa et al. 2019). Preliminary data from the CFTs has shown benefits from adding a third active ingredient (carbendazim) in the mixture (Santana et al. 2019a, b, 2020) and more data will become available in the near future to confirm this.

Another important outcome of systematic reviews is the possibility to identify knowledge gaps (Koricheva and Gurevitch 2014; Nakagawa et al. 2017). Our study shows clearly the need to invest resources on the analysis of DON data. The limited number of studies testing the effect of DMI+QoI premixes, both from published and CFT sources, reporting DON data (Baseggio et al. 2017; Bonfada et al. 2019; Feksa et al. 2019; Spolti et al. 2013) prevents us from obtaining reliable estimates of mycotoxin reduction for large databases as elsewhere (Paul et al. 2018). Thus far, there is very limited evidence of the effect of one or two applications of premixes, during flowering period, on FHB, yield and DON, which are composed of different combinations of QoIs and DMIs that can act differently (Blandino et al. 2006; Feksa et al. 2019; Paul et al. 2018; Zhang et al. 2009).

\section{Acknowledgements}

The first and senior author acknowledges the financial support provided by the Conselho Nacional de Desenvolvimento Científico e Tecnológico (CNPq/Brazil) for scholarship and research fellowship (PQ-306857/2015-4), respectively. We also acknowledge the financial support provided by the Fundação de Amparo à Pesquisa do Estado de Minas Gerais (Fapemig/Brazil) for a research grant (APQ-03945-16). All other authors are thankful to 
their institutions and teams for providing the support during the conduction of field experiments and collection of the data.

\section{Data availability statement}

All data, including graphical work, were processed and analyzed with $\mathrm{R}$ version 3.6.0 ( $\mathrm{R}$ Core Team 2019). Scripts were prepared in R Markdown and organized as a research compendium available at https://osf.io/ge7ux/. A website was generated to better visualize the scripts where all data and analyses are documented, reproducible and openly available at https://git.io/JUDyk

\section{Author's contribution}

JPB analysed the data and wrote the manuscript. MRD and FJM contributed to the literature review and writing. FMS, DL, CCS, CAS, DFC, WSV, LJD, CWG, PK, HRF conducted the trials and contributed data and comments on the manuscripts. EMD conceptualized the work, provided input on the data analysis and wrote the manuscript.

\section{Conflict of interests}

The authors declare that they have no conflict of interests.

\section{Literature Cited}

AGROLINK. 2020. Cotações. Available at: https://www.agrolink.com.br/cotacoes/ [Accessed January 6, 2020]. 
ANVISA. 2011. Resolução RDC nº 7, de 18 de fevereiro de 2011. Dispõe sobre limites máximos tolerados (LMT) para micotoxinas em alimentos. Page 66 in: Diário Oficial da União, Poder Executivo, Brasília, 26 fev. 2011. Seção 1.

ANVISA. 2017. Resolução RDC $n^{\circ}$ 138, de 8 de fevereiro de 2017. Altera a Resolução da Diretoria Colegiada $\mathrm{RDC} \mathrm{n}^{\circ}$ 7, de 18 de fevereiro de 2011, que dispõe sobre limites máximos tolerados (LMT) para micotoxinas em alimentos, para alterar os LMT da micotoxina deoxinivalenol (DON) em trigo e produtos de trigo prontos para oferta ao consumidor e os prazos para sua aplicação. Page 45 in: Diário Oficial da União, Poder Executivo, Brasília, 9 de fev. 2017. Seção 1.

Barro, J. P., Forte, C. T., Trentin, D., Scariot, M., and Milanesi, P. M. 2017. Effectiveness of different fungicide formulations and number of applications in controlling wheat leaf rust. Summa Phytopathologica. 43:276-280.

Barro, J. P., Meyer, M. C., Godoy, C. V., Dias, A. R., Utiamada, C. M., Jaccoud Filho, D. de S., Wruck, D. S. M., Borges, E. P., Siqueri, F., Juliatti, F. C., Campos, H. D., Nunes, J., Carneiro, L. C., Da Silva, L. H. C. P., Martins, M. C., Balardin, R. S., Zito, R. K., Furlan, S. H., Venâncio, W. S., and Del Ponte, E. M. 2019. Performance and profitability of fungicides for managing soybean white mold: a 10-year summary of cooperative trials. Plant Disease. 103:2212-2220.

Baseggio, A. V., Zilio, M., Mantovani, A. and Piva, C. A. G. 2017. Efeito da aplicação de 
fungicidas sobre desoxinivalenol em grãos de trigo. Unoesc \& Ciência. 8:35-42.

Blandino, M., Minelli, L., and Reyneri, A. 2006. Strategies for the chemical control of Fusarium head blight: Effect on yield, alveographic parameters and deoxynivalenol contamination in winter wheat grain. European Journal of Agronomy. 25:193-201.

Blandino, M., Pascale, M., Haidukowski, M., and Reyneri, A. 2011. Influence of agronomic conditions on the efficacy of different fungicides applied to wheat at heading: effect on flag leaf senescence, Fusarium head blight attack, grain yield and deoxynivalenol contamination. Italian Journal of Agronomy. 6:204-211.

Bolanos-Carriel, C., Wegulo, S. N., Baenziger, P. S., Funnell-Harris, D,. Hallen-Adams, H. E. and Eskridge, K. M. 2020. Effects of fungicide chemical class, fungicide application timing, and environment on Fusarium head blight in winter wheat. European Journal of Plant Pathology. https://doi.org/10.1007/s10658-020-02109-3

Bonfada, E. B., Honnef, D., Friedrich, M. T., Boller, W. and Deuner, C. C. 2019. Performance of fungicides on the control of fusarium head blight (Triticum aestivum L.) and deoxynivalenol contamination in wheat grains. Summa Phytopathologica. 45:374-380.

Casa, R. T., Reis, E. M., Blum, M. M. C., Bogo, A., Scheer, O., and Zanata, T. 2004. Danos causados pela infecção de Gibberella zeae em trigo. Fitopatologia Brasileira. 29:289-293. 
Dalla Lana, F., Paul, P. A., Godoy, C. V., Utiamada, C. M., da Silva, L. H. C. P., Siqueri, F. V., Forcelini, C. A., Jaccoud Filho, D. S., Wruck, D. S. M., Borges, E. P., Juliatti, F. C., Campos, H. D., Nunes, J., Carneiro, L. C., Canteri, M. G., Ito, M. F., Meyer, M. C., Martins, M. C., Balardin, R. S., Furlan, S. H., Carlin, V. J., and Del Ponte, E. M. 2018. Meta-analytic modeling of the decline in performance of fungicides for managing soybean rust after a decade of use in Brazil. Plant Disease. 102:807-817.

Dardis, J., and Walsh, E. J. 2000. Studies on the effectiveness of metconazole in controlling Fusarium head blight caused by Fusarium culmorum in spring wheat (Triticum aestivum L.) Cereal Research Communication. 28:443-448.

De Wolf, E. D., Madden, L. V. and Lipps, P. E. 2003. Risk assessment models for Fusarium head blight epidemics based on within-season weather data. Phytopathology. 93:428-435.

Del Ponte, E. M., Fernandes, J. M. C., and Pavan, W. 2005. A risk infection simulation model for Fusarium head blight of wheat. Fitopatologia. Brasileira. 30:634-642.

Del Ponte, E.M., Garda-Buffon, J., and Badiale-Furlong, E. 2012. Deoxynivalenol and nivalenol in commercial wheat grain related to Fusarium head blight epidemics in Southern Brazil. Food Chemistry. 132: 1087-1091.

Del Ponte, E. M., Spolti, P., Ward, T. J., Gomes, L. B., Nicolli, C. P., Kuhnem, P. R., Silva, C. N., and Tessmann, D. J. 2015. Regional and field-specific factors affect the composition of 
Fusarium head blight pathogens in subtropical no-till wheat agroecosystem of Brazil. Phytopathology. 105: 246-254.

Duan, Y., Lu, F., Zhou, Z., Zhao, H., Zhang, J., Mao, Y., Li, M., Wang, J., and Zhou, M. 2020. Quinone outside inhibitors affect DON biosynthesis, mitochondrial structure and toxisome formation in Fusarium graminearum. Journal of Hazardous Materials. doi: https://doi.org/10.1016/j.jhazmat.2020.122908

Duffeck, M. R., Tibola, C. S., Guarienti, E. M., and Del Ponte, Del Ponte, E. M. 2017. Survey of mycotoxins in Southern Brazilian wheat and evaluation of immunoassay methods. Scientia Agricola. 74:343-348.

Duffeck, M. R., Alves, K. S., Machado, F. J., Esker, P. D., and Del Ponte, E. M. 2020. Modeling yield losses and fungicide profitability for managing Fusarium head blight in Brazilian spring wheat. Phytopathology. 110: 370-378.

Edwards Molina, J. P., Paul, P. A., Amorim, L., Silva, L. H. C. P., Siqueri, F. V., Borges, E. P., Campos, H. D., Nunes, J., Meyer, M. C., Martins, M. C., Balardin, R. S., Carlin, V. J., Grigolli, J. F. J., Belufi, L. M. R., and Godoy, C. V. M. 2019. Meta-analysis of fungicide efficacy on soybean target spot and cost-benefit assessment. Plant Pathology. 68:94-106.

Edwards, S. G., Pirgozliev, S. R., Hare, M. C., and Jenkinson, P. 2001. Quantification of trichothecene-producing Fusarium species in harvested grain by competitive pcr to 
determine efficacies of fungicides against fusarium head blight of winter wheat. Applied and Environmental Microbiology. 67:1575-1580.

Ellner, F. M. 2005. Results of long-term field studies into the effect of strobilurin containing fungicides on the production of mycotoxins in several winter wheat varieties. Mycotoxin Research. 21:112-115.

Feksa, H. R., Do Couto, H. T. Z., Garozi, R., De Almeida, J. L., Gardiano, C. G., and Tessmann, D. J. 2019. Pre- and postinfection application of strobilurin-triazole premixes and single fungicides for control of Fusarium head blight and deoxynivalenol mycotoxin in wheat. Crop Protection. 117:128-134.

Goswami, R. S., and Kistler, H. C. 2004. Heading for disaster: Fusarium graminearum on cereal crops. Molecular Plant Pathology. 5:515-525.

Higgins J. P., Jackson, D., Barrett, J. K., Lu, G., Ades, A. E., and White, I. R. 2012. Consistency and inconsistency in network meta-analysis: concepts and models for multi-arm studies. Research Synthesis Methods. 3:98-110.

Koricheva, J. and Gurevitch, J. 2014. Uses and misuses of meta-analysis in plant ecology. Journal of Ecology. 102:828-844.

Machado, F. J., Santana, F. M., Lau, D., and Del Ponte, E. M. 2017. Quantitative review of the 
effects of triazole and benzimidazole fungicides on Fusarium head blight and wheat yield in Brazil. Plant Disease. 101:1633-1641.

Madden, L. V., and Paul, P. A. 2011. Meta-analysis for evidence synthesis in plant pathology: an overview. Phytopathology. 101:16-30.

Madden, L. V., Piepho, H. -P., and Paul, P. A. 2016. Statistical models and methods for network meta-analysis. Phytopathology. 106:792-806.

Magan, N., Hope, R., Colleate, A. and Baxter, E. S. 2002. Relationship between growth and mycotoxin production by Fusarium species, biocides and environment. European Journal of Plant Pathology. 108:685-690.

Mallmann, C. A., Dilkin, P., Mallmann, A. O., Oliveira, M. S., Adaniya, Z. N. C., Tonini, C. 2017. Prevalence and levels of deoxynivalenol and zearalenone in commercial barley and wheat grain produced in Southern Brazil: an eight-year (2008 to 2015) summary. Tropical Plant Pathology. 42:146-152.

McMullen, M., Bergstrom, G. C., De Wolf, E., Dill-Macky, R., Hershman, D. E., Shaner, G., and Van Sanford, D. 2012. A unified effort to fight an enemy of wheat and barley: Fusarium head blight. Plant Disease. 96:1712-1728.

Mesterházy, Á., Bartók, T., and Lamper, C. 2003. Influence of wheat cultivar, species of 
Fusarium, and isolate aggressiveness on the efficacy of fungicides for control of Fusarium head blight. Plant Disease. 87:1107-1115.

Mesterházy, Á., Tóth, B., Varga, M., Bartók, T., Szabó-Hevér, Á., Farády, L., and Lehoczki-Krsjak, S. 2011. Role of fungicides, application of nozzle types, and the resistance level of wheat varieties in the control of Fusarium head blight and deoxynivalenol. Toxins. 3:1453-1483.

Mesterházy, Á., Varga, M., Tóth, B. Kótai, C., Bartók, T., Véha, A., Ács, K., Vágvölgyi, C., and Lehoczki-Krsjak, S. 2018. Reduction of deoxynivalenol (DON) contamination by improved fungicide use in wheat. Part 1. Dependence on epidemic severity and resistance level in small plot tests with artificial inoculation. European Journal of Plant Pathology. 151:39-55.

Mueller, K. F., Meerpohl, J. J., Briel, M., Antes, G., Elm, E. von, Lang, B., Gloy, V., Motschall, E., Schwarzer, G., and Bassler, D. 2013. Detecting, quantifying and adjusting for publication bias in meta-analyses: protocol of a systematic review on methods. Systematic Reviews. 2:60.

Nakagawa, S., Noble, D. W. A., Senior, A. M. and Lagisz, M. Meta-evaluation of meta-analysis: ten appraisal questions for biologists. BMC Biology. 15:18.

Oerke, E. C., Beck, C., and Dehne, H. W. 2001. Physiological effects of strobilurins on wheat yield. Phytopathology. 91:67-71. 
Pannucci, C. J., and Wilkins, E. G. 2010. Identifying and avoiding bias in research. Plastic and Reconstructive Surgery. 126:619-625.

Paul, P. A., Lipps, P. E., Hershman, D. E., McMullen, M. P., Draper, M. A., and Madden, L. V. 2008. Efficacy of triazole-based fungicides for Fusarium head blight and deoxynivalenol control in wheat: A multivariate meta-analysis. Phytopathology. 98:999-1011.

Paul, P. A., McMullen, M. P., Hershman, D. E., and Madden, L. V. 2010. Meta-analysis of the effects of triazole-based fungicides on wheat yield and test weight as influenced by Fusarium head blight intensity. Phytopathology. 100:160-171.

Paul, P. A., Bradley, C. A., Madden, L. V., Lana, F. D., Bergstrom, G. C., Dill-Macky, R., Esker, P. D., Wise, K. A., McMullen, M., Grybauskas, A., Kirk, Milus, W. W., E., and Ruden, K. 2018. Meta-analysis of the effects of QoI and DMI fungicide combinations on Fusarium head blight and deoxynivalenol in wheat. Plant Disease. 102:2602-2615.

Piepho, H. P. 2014. Network meta-analysis made easy: detection of inconsistency using factorial analysis-of-variance models. BMC Medical Research Methodology. 14:61.

Pirgozliev, S. R., Edwards, S. G., Hare, M. C., and Jenkinson, P. 2002. Effect of dose rate of azoxystrobin and metconazole on the development of Fusarium head blight and the accumulation of deoxynivalenol (DON) in wheat grain. European Journal of Plant Pathology. 
108:469-478.

Ponts, N. 2015. Mycotoxins are a component of Fusarium graminearum stress-response system. Frontiers in microbiology. 6: 1234. https://doi.org/10.3389/fmicb.2015.01234

Ransom, J., and McMullen, M. 2008. Yield and disease control on hard winter wheat cultivars with foliar fungicides. Agronomy Journal. 100:1130-1137.

Reis, E. M., Blum, M. M. C., Casa, R., and Medeiros, C. A. 1996. Grain losses caused by the infection of wheat heads by Gibberella zeae in southern Brazil, from 1984 to 1994. Summa Phytopathologica. 22:134-137.

R Core Team. 2019. R: A language and environment for statistical computing. R Foundation for Statistical Computing,Vienna, Austria. https://www.R-project.org/.

Santana, F. M., Lau, D., Maciel, J. L. N., Cargnin, A., Seixas, C. D. S., Bassoi, M. C., Schipanski, C. A., Feksa, H., Casa, R. T., Wesp, C., Navarini, L., and Blum, M. 2012. Eficiência de fungicidas para controle de giberela em trigo: resultados dos ensaios cooperativos - safra 2011. Comunicado Técnico 23. Embrapa Trigo, Passo Fundo, Brazil.

Santana, F. M., Lau, D., Cargnin, A., Seixas, C. D. S., Schipanski, C. A., Feksa, H., Wesp, C., Blum, M., and Bassoi, M. C. 2014. Eficiência de fungicidas para controle de giberela em trigo: resultados dos ensaios cooperativos - safra 2012. Comunicado Técnico 336. Embrapa Trigo, 
Passo Fundo, Brazil.

Santana, F. M., Lau, D., Aguilera, J. G., Sbalcheiro, C. C., Feksa, H., Floss, L. G., and Guterres, C. W. 2016a. Eficiência de fungicidas para controle de Gibberella zeae em trigo: resultados dos Ensaios Cooperativos - safra 2013. Comunicado Técnico 362. Embrapa Trigo, Passo Fundo, Brazil.

Santana, F. M., Lau, D., Sbalcheiro, C. C., Schipanski, C. A., Seixas, C. D. S., Feksa, H., Floss, L. G., Guterres, C. W., and Venâncio, W. S. 2016b. Eficiência de fungicidas para controle de Gibberella zeae em trigo: resultados dos Ensaios Cooperativos - safra 2014. Comunicado Técnico 364. Embrapa Trigo, Passo Fundo, Brazil.

Santana, F. M., Lau, D., Sbalcheiro, C. C., Feksa, H., Guterres, C. W., and Venâncio, W. S. 2016c. Eficiência de fungicidas para controle de Gibberella zeae em trigo: resultados dos Ensaios Cooperativos - safra 2015. Comunicado Técnico 368. Embrapa Trigo, Passo Fundo, Brazil.

Santana, F. M., Lau, D., Sbalcheiro, C. C., Guterres, C. W., Venâncio, W. S., Seixas, C. D. S. and Nicolau, M. 2019a. Eficiência de fungicidas para controle de giberela do trigo: resultados dos Ensaios Cooperativos - Safra 2016. Circular Técnica 39. Embrapa Trigo, Passo Fundo, Brazil.

Santana, F. M., Lau, D., Sbalcheiro, C. C., Feksa H., Kuhnem, P. R., Schipanski, C. A., 
Guterres, C. W., Venâncio, W. S., Dallagnol, L. J., Chagas, D. F. and Nicolau, M. 2019b. Eficiência de fungicidas para controle de giberela do trigo: resultados dos Ensaios Cooperativos - safra 2017. Circular Técnica 44. Embrapa Trigo, Passo Fundo, Brazil.

Santana, F. M., Lau, D., Sbalcheiro, C. C., Schipanski, C. A., Venâncio, W. S., Dallagnol, L. J., Guterres, C. W., Kuhnem, P. R. and Chagas, D. F. 2020. Eficiência de fungicidas para controle de giberela do trigo: resultados dos Ensaios Cooperativos - Safra 2018. Circular Técnica 52. Embrapa Trigo, Passo Fundo, Brazil.

Simpson, D. R., Weston, G. E., Turner, J. A., Jennings, P., and Nicholson, P. 2001. Differential control of head blight pathogens of wheat by fungicides and consequences for mycotoxin contamination of grain. European Journal of Plant Pathology. 107: 421-431.

Spolti, P., Guerra, D. S., Badiale-Furlong, E., and Del Ponte, E. M. 2013. Single and sequential applications of metconazole alone or in mixture with pyraclostrobin to improve Fusarium head blight control and wheat yield in Brazil. Tropical Plant Pathology. 38:85-96.

Viechtbauer, W. 2010. Conducting Meta-analyses in R with the metafor Package. Journal of Statistical Software. 36:1-48.

Wegulo, S. N., Bockus, W. W., Nopsa, J., De Wolf, E. D., Eskridge, K. M., Peiris, K. H. S., and Dowell, F. E. 2011. Effects of integrating cultivar resistance and fungicide application on Fusarium head blight and deoxynivalenol in winter wheat. Plant Disease. 95:554-560. 
Wegulo, S. N., Baenziger, P. S., Hernandez Nopsa, J., Bockus, W. W., and Hallen-Adams, H. 2015. Management of Fusarium head blight of wheat and barley. Crop Protection. 73:100-107.

Willyerd, K. T., Li, C., Madden, L. V., Bradley, C. A., Bergstrom, G. C., Sweets, L. E., McMullen, M., Ransom, J. K., Grybauskas, A., Osborne, L., Wegulo, S. N., Hershman, D. E., Wise, K., Bockus, W. W., Groth, D., Dill-Macky, R., Milus, E., Esker, P. D., Waxman, K. D., Adee, E. A., Ebelhar, S. E., Young, B. G., and Paul, P. A. 2012. Efficacy and stability of integrating fungicide and cultivar resistance to manage Fusarium head blight and deoxynivalenol in wheat. Plant Disease. 96:957-967.

Zhang, Y. J., Fan, P. S., Zhang, X., Chen, C. J., and Zhou, M. G. 2009. Quantification of Fusarium graminearum in harvested grain by real-time polymerase chain reaction to assess efficacies of fungicides on fusarium head blight, deoxynivalenol contamination, and yield of winter wheat. Phytopathology. 99:95-100. 

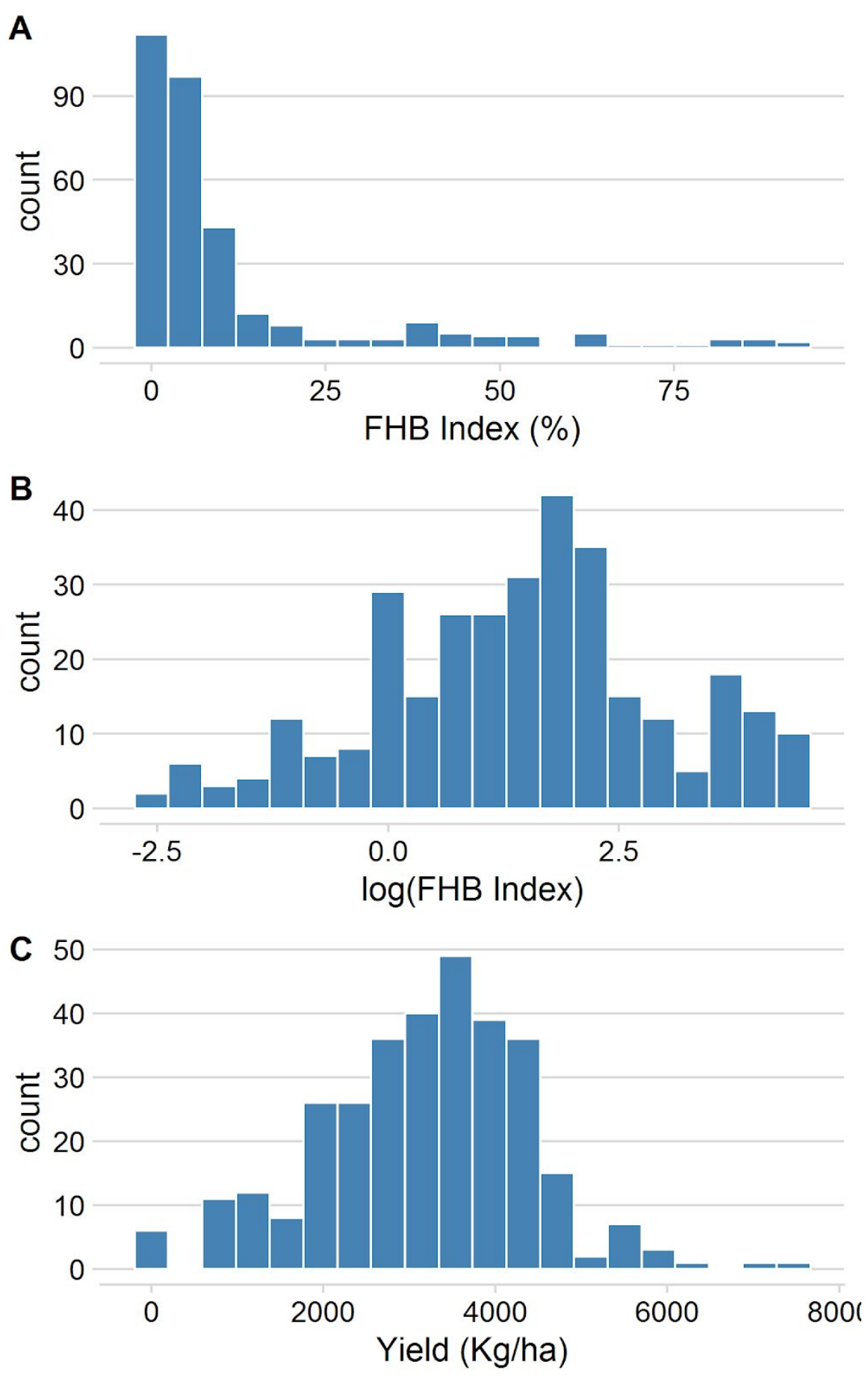

Fig. S1: Histograms for the distribution of FHB index (A) and wheat grain yield (C) to check normality; B: log-transformed FHB index data for normalizing the distribution and use in the meta-analysis. 

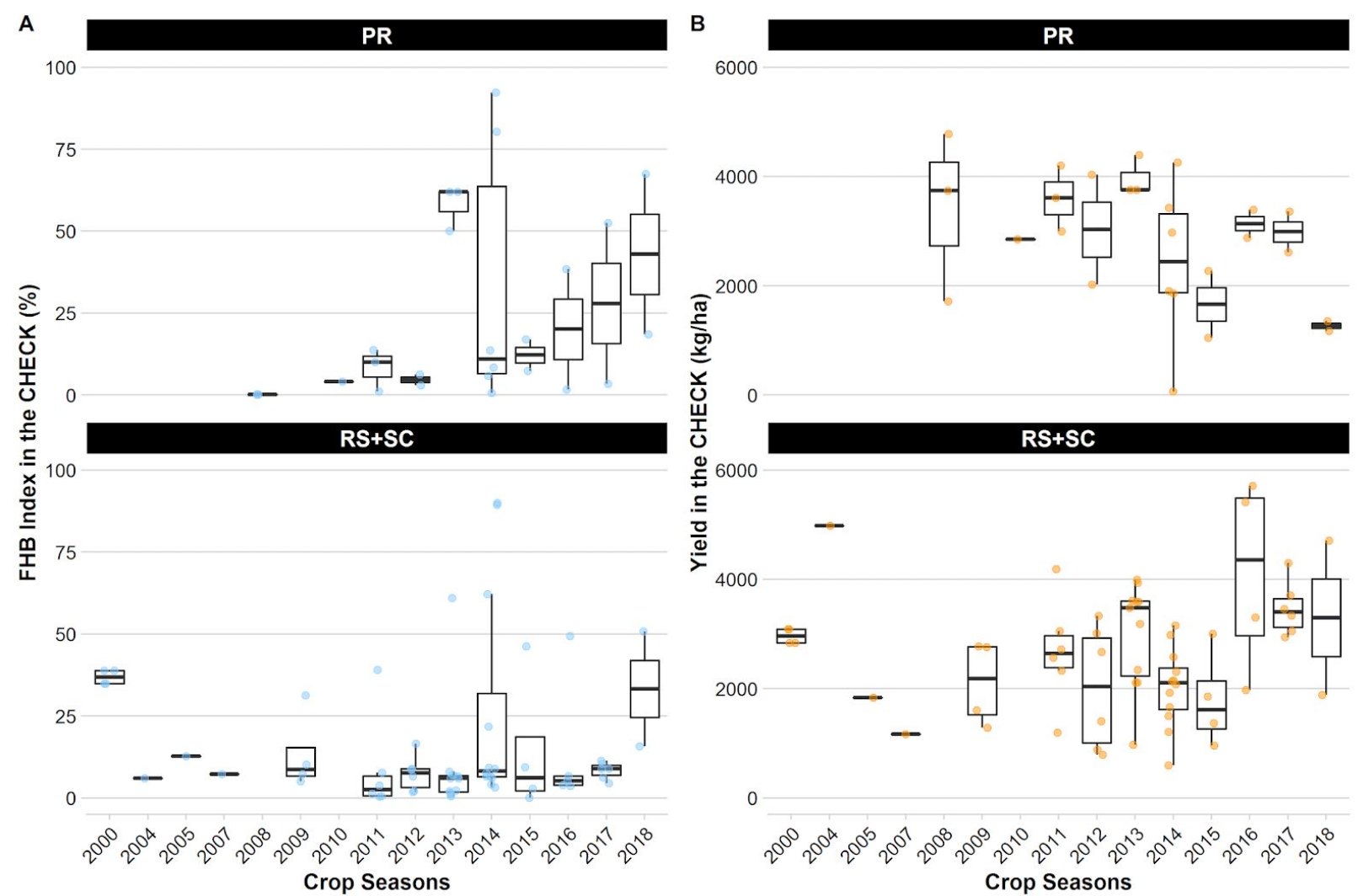

Fig. S2: Box plots for the within-season variation across trials of FHB Index (A) and wheat grain yield (B) in the nontreated CHECK of 73 trials conducted in each Brazilian state. Trials in Rio Grande do Sul (RS) and Santa Catarina (SC) state were combined due geographic localization. The thick horizontal line inside the box represents the median, the limits of the box represent the lower and upper quartiles, and the circles represent yearly means. 


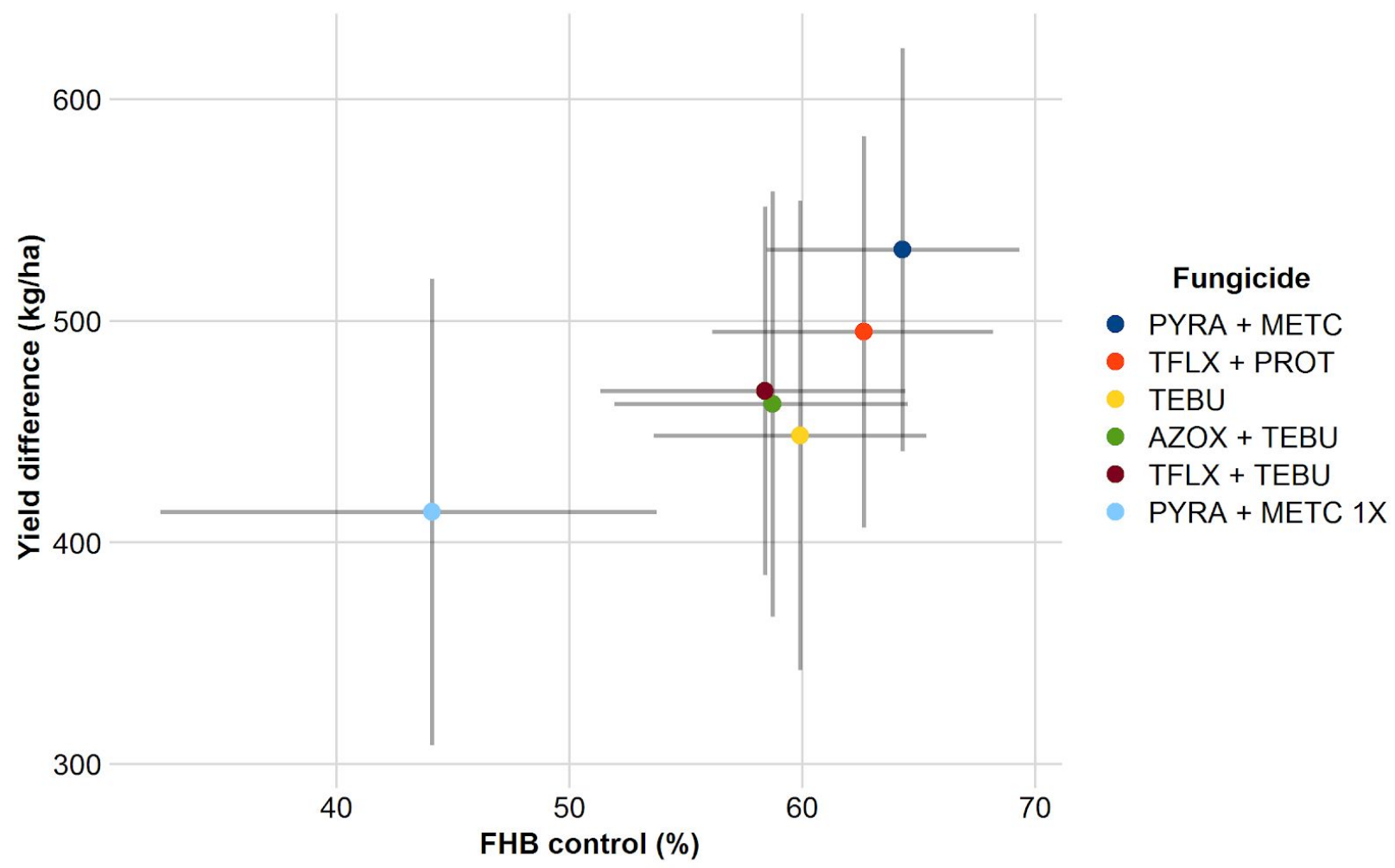

Fig. S3. Relationship between percent reduction of Fusarium Head Blight (FHB) and yield difference relative to non-treated check, for six fungicides evaluated across 73 independent field trials in Brazil from 2000 to 2018. Bars show the upper and lower limits of 95\% confidence intervals around point estimates for both responses. See Table 1 for complete information of the evaluated fungicides. 